\title{
COMPARATIVE STUDY OF CEMENT CONCRETE AND GEOPOLYMER MASONRY BLOCKS
}

\author{
Kishan L.J' ${ }^{1}$, Radhakrishna ${ }^{2}$ \\ ${ }^{I} P G$ Student, ${ }^{2}$ Associate Dean, Department of Civil Engineering, RV college of Engineering, Bangalore 560059 \\ ljkishan@gmail.com,chakavelu_rk@yahoo.com
}

\begin{abstract}
It is well known that the production of cement is extremely resource and energy intensive process producing an equal amount of $\mathrm{CO}_{2}$ per ton of cement. Hence, due to growing environmental concerns of the cement industry, there is a need to develop alternative materials such as fly ash, Ground granulated blast furnace slag (GGBS). Also there is a need to develop masonry units using these alternative materials for sustainability. Geopolymer technology makes use of fly ash which is a byproduct of thermal power plants. In the present research, cement and geopolymer blocks are produced by the same method. The basic properties of these masonry units such as compressive strength, density, modulus of elasticity, Initial rate of absorption (IRA) and water absorption are determined and compared. The results indicate that Geopolymer blocks posses superior properties compared to traditional cement blocks. Geopolymer blocks can be recommended for the use as masonry units for structural masonry. Thus the use of conventional cement can be eliminated.
\end{abstract}

Keywords: Geopolymer, cement, comparative study, compressive strength, water absorption, stress strain relationship.

\section{INTRODUCTION}

Masonry is the building of structures from individual units that are usually bound together by means of mortar [1]. Concrete block masonry is a common construction material in India because of its abundance, low cost and availability of skilled labour [2]. The main drawback of cement concrete blocks is consumption of cement which is a major contributor to the greenhouse effect and the global warming, it is necessary to consider this with very severe regulations and limitations [3]. At the same time the demand for industrial and domestic energy results in the production of a large volume of fly ash from solid coal fuel, which may increase in the world on an unprecedented scale in future [4]. Therefore, fly ash should not only be disposed of safely to prevent environmental pollution, but should be treated as a valuable resource. Production of building materials, particularly bricks/blocks using fly ash is considered to be one of the solutions to the ever increasing fly ash disposal problem in the country [5]. All the three methods of utilizing fly ash are considered in construction in different forms. Cement can be replaced partly with fly ash, Geopolymer and FaL-G can be used in the form of masonry blocks for better and strength and durability [6].

\section{EXPERIMENTAL WORK}

Cement used for this project is of 53 grade. As per IS: 12269 physical properties of cement are determined. It has an initial setting time of 43 minutes, final setting time of 3hour $38 \mathrm{mins}$ and Specific gravity is 3.1. Locally available river Sand is used as fine aggregate in the production of cement and geopolymer blocks. Fine aggregates passing through $4.75 \mathrm{~mm}$ sieve were taken for the experiment. The physical and chemical properties of fly ash used in this investigation are shown in Tables 1 and 2. The ratio of $\mathrm{SiO} 2$ and $\mathrm{Al} 2 \mathrm{O} 3$ of the fly ash is around 2, suitable to use for making low $\mathrm{CO} 2$ cements. The physical and chemical properties of GGBS are indicated in Table 3. Since it contains aluminum oxide and silica oxide; it is suitable for making of the Geopolymers.

Table 1 Physical Properties of fly ash

\begin{tabular}{|l|l|l|l|l|}
\hline $\begin{array}{l}\text { Specific } \\
\text { Gravity }\end{array}$ & $\begin{array}{l}\text { Percentage Finer than } \\
45 \mu\end{array}$ & $\begin{array}{l}\text { Fineness, } \\
\mathrm{m} 2 / \mathrm{Kg}\end{array}$ & Loss on Ignition & Lime reactivity, MPa \\
\hline 2.40 & 0.00 & 1134.1 & 0.9 & 7.23 \\
\hline
\end{tabular}


Table 2 Chemical Properties of fly ash

\begin{tabular}{|l|l|l|l|l|l|l|l|l|}
\hline \multirow{2}{*}{ Binder } & \multicolumn{9}{|l|}{ Chemical Composition in percentage } \\
\cline { 2 - 9 } & $\mathrm{Al2O} 3$ & $\mathrm{Fe} 2 \mathrm{O} 3$ & $\mathrm{SiO} 2$ & $\mathrm{MgO}$ & $\mathrm{SO} 3$ & $\mathrm{Na} 2 \mathrm{O}$ & $\begin{array}{l}\text { Total } \\
\text { Chlorides }\end{array}$ & $\mathrm{CaO}$ \\
\hline Fly Ash & 31.23 & 1.5 & 61.12 & 0.75 & 0.53 & 1.35 & 0.06 & 3.20 \\
\hline
\end{tabular}

Table 3 Properties of GGBS

\begin{tabular}{|l|l|l|l|l|l|l|l|l|l|l|l|}
\hline Specific & Fineness & Insolubl & Loss on & \multicolumn{2}{l|}{ Chemical Composition in percentage } \\
\cline { 5 - 11 } Gravity & $\mathrm{m} 2 / \mathrm{Kg}$ & e residue & Ignition & $\mathrm{Al} 2 \mathrm{O} 3$ & $\mathrm{Fe} 2 \mathrm{O} 3$ & $\mathrm{SiO} 2$ & $\mathrm{MgO}$ & $\mathrm{MnO}$ & $\mathrm{S}$ & $\mathrm{Chlorides}$ & $\mathrm{CaO}$ \\
\hline 2.90 & 370.0 & 0.05 & 0.3 & 13.24 & 0.65 & 37.21 & 8.65 & 0.325 & 2.23 & 0.003 & 37.23 \\
\hline
\end{tabular}

Alkaline solution was prepared using Sodium hydroxide, Sodium silicate and water. Calculated amount of Sodium hydroxide and Sodium silicate was added to water in a container. This mixture was mixed thoroughly to dissolve all the particles. The solution was stirred once in an hour for five to six times to avoid deposits. This solution was used after 24 hours of its preparation. For the preparation of 1liter of 1M (1 molar) solution, $40 \mathrm{~g}$ of sodium hydroxide and equal amount of sodium silicate powder were added to 1liter of water.

\subsection{Preparation of Blocks}

The binder used in the preparation of cement block is 53grade cement and that for geopolymer block, Fly ash and GGBS.
Fine aggregate (River sand) passing through $4.75 \mathrm{~mm}$ sieve was used.

The binder was taken in a pan; the aggregate was added and mixed thoroughly till homogenous colour is obtained. Then water/ alkaline solution was added to the dry mix. It is mixed thoroughly and wet mix is used to prepare the blocks by manual compression. Mardini, a manually operated device is used for this purpose. Tables 4 and 5 give the proportioning of cement and geopolymer mortar respectively.

Table 4 Proportioning of cement mortar

\begin{tabular}{|l|l|l|}
\hline Size of the block & Mortar proportion & W/C Ratio \\
\hline $190 \mathrm{~mm} \times 230 \mathrm{~mm} 100 \mathrm{~mm}$ & $1: 6$ & 0.2 \\
\hline
\end{tabular}

Table 5 Proportioning of Geopolymer mortar

\begin{tabular}{|l|l|l|l|l|}
\hline Size of the block & Mortar proportion & Flyash: GGBS & F/B Ratio & Molarity \\
\hline $190 \mathrm{mmx} 230 \mathrm{mmx} 100 \mathrm{~mm}$ & $1: 1$ & $80: 20$ & 0.2 & 14 \\
\hline
\end{tabular}

Cement blocks are cured by placing in water for 28 days. Geopolymer blocks are cured in open air. After 28 days, various tests were carried out to obtain the properties of blocks such as Dimensionality Test, Dry density, Water absorption Test, Initial rate of absorption (IRA), Compressive strength and Modulus of elasticity. Dimensionality test is done according to the IS: 1077-1992. Dry density test is performed to find the brick in dry state. The weight of oven dry brick specimen was measured and the average dimension (i.e.) length, breadth and thickness of block were measured. Initial rate of absorption test was conducted as per the guidance given in ASTM C67. Initial rate of absorption is the measure of block suction and represents the weight of water absorbed in 1 minute by the bed face of the block when immersed to a depth of $3 \mathrm{~mm}$ in water. Water absorption test is performed as per IS: $3495-1976$ part 2. Compressive strength test was conducted as per the guidance given in IS: 1077-1992. To determine the stress-strain behaviour, the specimen was placed along with $100 \mathrm{~mm}$ demec gauge in CTM. Deformation was measured using Demec gauge at suitable load intervals. 


\section{RESULTS AND DISCUSSION}

Dimensionality test is done according to the IS: 1077-1992. The average dimensions of the cement and geopolymer blocks obtained are given in Table 6 . The dimensions of the blocks are within the limits of non modular size specified by IS: 1077-1992. Different tests on masonry blocks were conducted at the age of 7,14 , and 28 day to determine their basic properties as indicated in Table 7. The results indicate that geopolymer blocks have lower dry density compared to cement blocks which is represented in Fig 1. As per Sarangpani [1], the IRA values for masonry units should be in the range $1.31-3.53 \mathrm{~kg} / \mathrm{m} 2 / \mathrm{min}$. The IRA values of geopolymer blocks were less compared to cement blocks which are represented in Fig 2. The percentage water absorption for all the blocks ranges from $6.5-10 \%$ which satisfies the limit of maximum $20 \%$ as per IS $3495-1976$ PART 2. From Fig 3 it can be observed that Water absorption of geopolymer blocks have been decreased at the later age and lesser compared to cement blocks. Strengths developed were in the range of $3.5-10 \mathrm{MPa}$ in cement blocks and $8.7-25 \mathrm{MPa}$ in geopolymer blocks. It can be seen that geopolymer blocks have excellent strength as compared to cement blocks. Compressive strength development of two different blocks with the age is indicated in the graph as shown in Fig 4. The test results of modulus of elasticity are indicated in the graph shown in Fig 5 and 6 respectively. The important results from the graphs are given in Table 8. It can be seen that initial tangent modulus of geopolymer block was higher than cement block. Maximum strain was taken by geopolymer block as compared to cement block.

Table 6 Results of Dimensionality test

\begin{tabular}{|c|c|c|c|c|}
\hline Type of block & Sides & No of Units & Dimension (mm) & Average $\operatorname{Dim}(\mathrm{mm})$ \\
\hline \multirow{3}{*}{ Cement blocks } & $\mathrm{L}$ & \multirow{3}{*}{20} & 4620 & 231 \\
\hline & $\mathrm{W}$ & & 3840 & 192 \\
\hline & $\mathrm{H}$ & & 2040 & 102 \\
\hline \multirow{3}{*}{ Geopolymer blocks } & $\mathrm{L}$ & \multirow{3}{*}{20} & 4600 & 230 \\
\hline & $\mathrm{W}$ & & 3820 & 191 \\
\hline & $\mathrm{H}$ & & 2040 & 102 \\
\hline
\end{tabular}

Table 7 Results of Basic Properties of blocks

\begin{tabular}{|l|l|l|l|l|l|}
\hline \multirow{3}{*}{ Type of block } & $\begin{array}{l}\text { No of } \\
\text { days }\end{array}$ & $\begin{array}{l}\text { Dry density } \\
\text { Kg/m3 }\end{array}$ & $\begin{array}{l}\text { IRA } \\
\text { Kg/m2/min }\end{array}$ & $\begin{array}{l}\text { Water absorption } \\
\%\end{array}$ & $\begin{array}{l}\text { Compressive strength } \\
\mathrm{MPa}\end{array}$ \\
\hline \multirow{3}{*}{ Cement block } & 7 & 1856.98 & 1.63 & 7.47 & 5.4 \\
\cline { 2 - 6 } & 14 & 1879.86 & 1.76 & 7.40 & 6.4 \\
\cline { 2 - 6 } & 28 & 1891.30 & 1.95 & 7.55 & 7.4 \\
\hline \multirow{2}{*}{$\begin{array}{l}\text { Geopolymer } \\
\text { block }\end{array}$} & 7 & 1836.38 & 1.68 & 7.81 & 8.7 \\
\cline { 2 - 6 } & 14 & 1847.44 & 1.98 & 7.74 & 19.53 \\
\hline
\end{tabular}

Table 8 Test details of modulus of elasticity

\begin{tabular}{|l|l|l|l|}
\hline Specimen & $\begin{array}{l}\text { Regression } \\
\text { coefficient (R) }\end{array}$ & $\begin{array}{l}\text { Initial } \\
\text { Modulus } \quad \begin{array}{l}\text { Tangent } \\
(\mathrm{MPa})\end{array}\end{array}$ & Maximum strain \\
\hline Cement block & 0.974 & 5426 & 0.00215 \\
\hline Geopolymer block & 0.912 & 6721 & 0.00359 \\
\hline
\end{tabular}




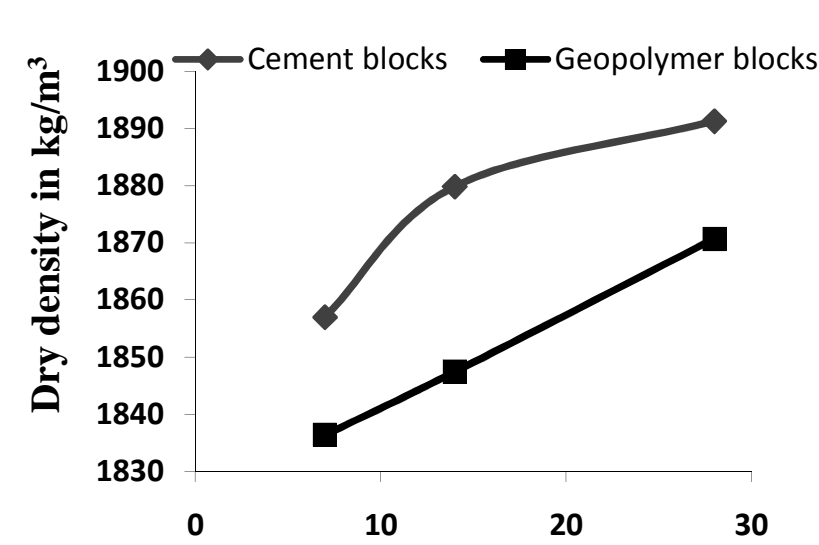

Age in days

Fig 1 Dry density of blocks

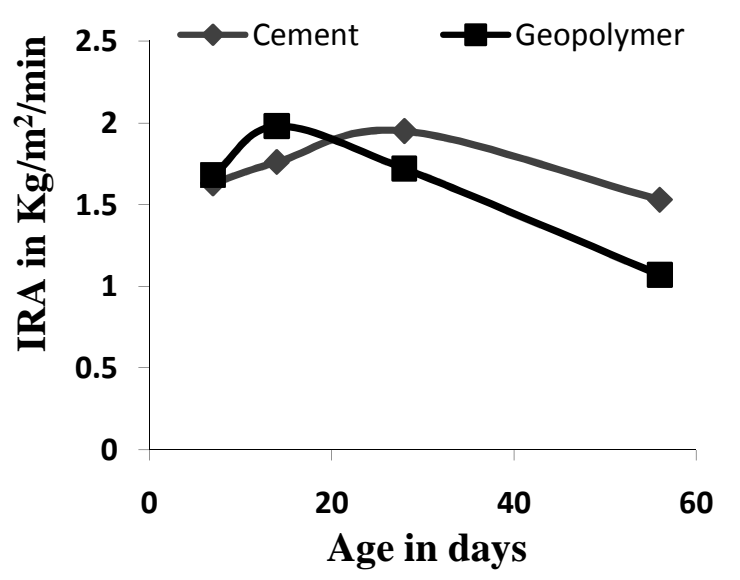

Fig 3 Water absorption of blocks

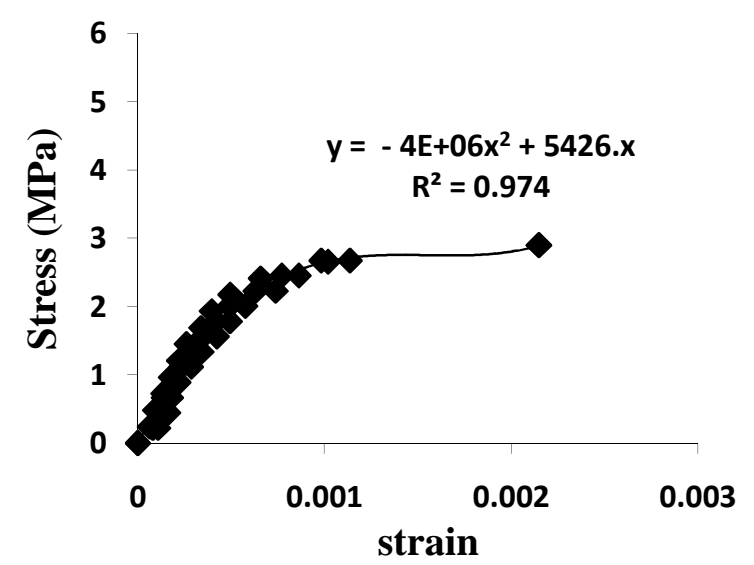

Fig 5 Stress Strain curve - Cement blocks

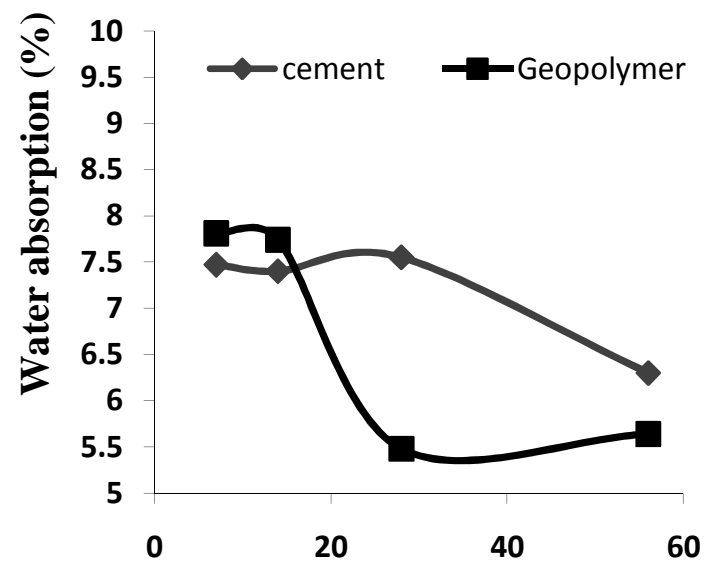

Age in days

Fig 2 Initial rate of absorption (IRA) of blocks

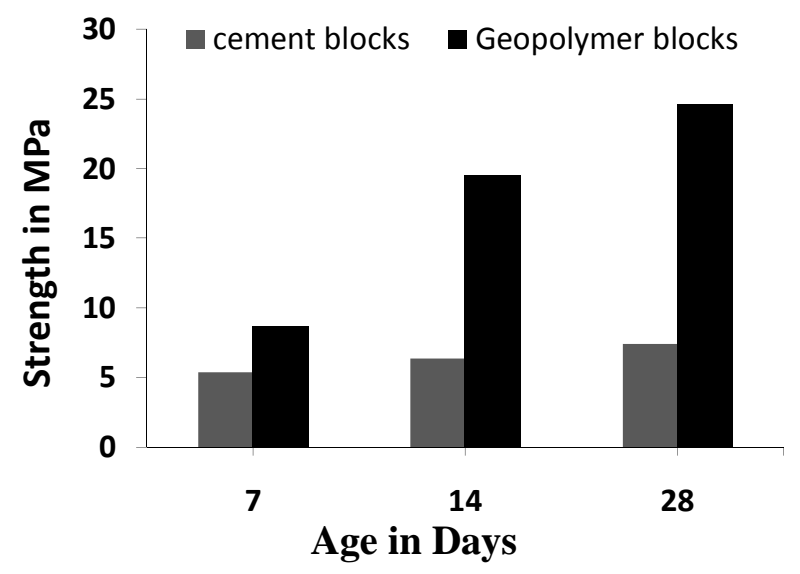

Fig 4 Compressive Strength of blocks

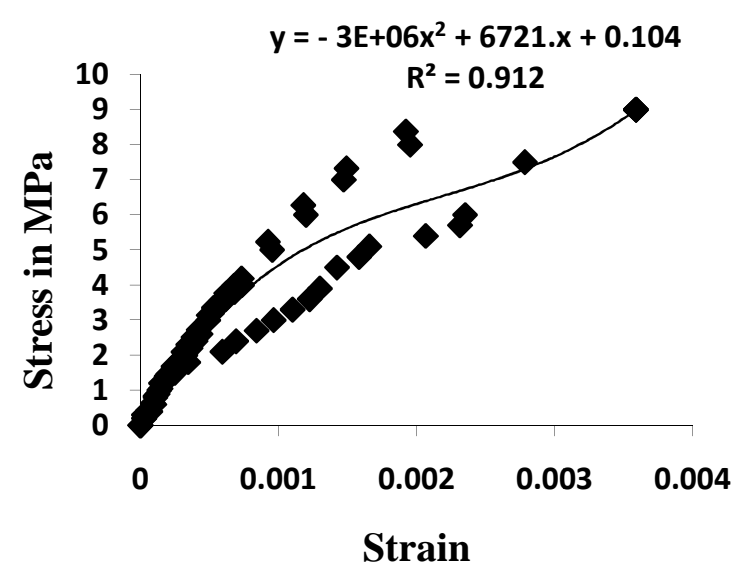

Fig 6 Stress Strain curve - Geopolymer blocks 


\section{CONCLUSIONS}

The following broad conclusions can be drawn with the limited study.

- Geopolymer blocks have low dry density and excellent strength compared to cement blocks.

- The compressive strength of geopolymer masonry block is as high as $25 \mathrm{MPa}$ at 28 days, which is much above the compressive strength of cement block.

- Water absorption and IRA of geopolymer blocks were less at the later age as compared to cement blocks.

- The modulus of elasticity of Geopolymer block is high as compared to cement block.

- Open air curing can be adopted for Geopolymer blocks no water is required.

- It is possible to manufacture masonry block without use of cement.

- Geopolymer blocks can be recommended for the use as masonry units for structural masonry.

\section{REFERENCES}

[1] G. Sarangapani, B. V. Venkatarama Reddy and K. S. Jagadish- Structural characteristics of bricks, mortars and masonry- Vol.29. No. 2 July-September 2002 pp. 101-107.

[2] Gihad Mohamad, Paulo B. Lourenco \&Humberto R. Roman- "Mechanics of Hollow concrete block masonry prisms under compression: Review and prospects"Science direct Cement \& Concrete Composites 29 (2007) pp181-192.

[3] G. S. Manjunath, Radhakrishna, C. Giridhar, Mahesh Jadhav- Compressive Strength Development in Ambient Cured Geo-polymer Mortar- International Journal of Earth Sciences and Engineering ISSN 09745904, Volume 04, No 06 SPL, October 2011, pp. 830834.

[4] N. Bhanumathidas, N. Kalidas - Sustainable Development through use of Fly Ash- National Seminar on Building Materials \& Technology for Sustainable Development; Ahmadabad: Jan 2005.

[5] Radhakrishna, A Shashishankar, B.C Udayashankarphenomenological model to re-proportion geopolymer compressed blocks- 33rd conference on our world in concrete \& structures: 25 - 27 august 2008, Singapore.

[6] Radhakrishna, Renuka Devi M.V and Udayashankar B.C- Use of fly ash in construction industries for sustainable development- Journal of Environmental Research and Development Vol. 3 No. 4, April-June 2009.

[7] Claudius S. Barbosa \&Paulo B. Lourenco Joao B. Hanai- "On the compressive strength prediction for concrete masonry prisms"- Materials and Structures (2010) pp43:331-344.
[8] David Garcı́a Jose,' T. San-Jose, Leire Garmendia, Rosa San-Mateos- Experimental study of traditional stone masonry under compressive load and comparison of results with design codes- Journal of Materials and Structures (2012) pp45:995-1006.

[9] Rui Sousa, Hipólito Sousa, Joa o Guedes- Diagonal compressive strength of masonry samples-experimental and numerical approach- Journal Materials and Structures DOI 10.1617/s11527-012-9933-z (2012).

[10] Mr._ K. Ramamurthy, Mr. V. Sathish, and Mr. R. Ambalavanan- Compressive Strength Prediction of Hollow Concrete Block Masonry Prisms- Structural Journal, January 1, 2000.

[11] Alternative building materials “ K.S.Jagadish, B.V.Venkatarama Reddy and K.S.Nanjunda Rao"

[12] Anupam Bhowmick, Somnath Ghosh- Effect of synthesizing parameters on workability and compressive strength of Fly ash based Geopolymer mortar- International journal of civil and structural engineering Volume 3, No 1, 2012.

[13] Daniel L.Y. Kong, Jay G. Sanjayan- Effect of elevated temperatures on geopolymer paste, mortar and concrete- Journal of Cement and Concrete Research 40 (2010) pp334-339.

[14] V. Bhikshma, M. Koti Reddy and T. Srinivas Rao- An Experimental investigation on properties of Geopolymer concrete (no cement concrete) - Asian journal of Civil Engineering (building and housing) vol. 13, no. 6 (2012) pp 841-853.

[15] K. Vijai, R. Kumutha and B. G. VishnuramExperimental Investigations on Mechanical Properties OF Geopolymer Concrete Composites- Asian Journal of Civil Engineering (Building and Housing) vol. 13, no. 1 (2012) pages 89-96.

[16] Qhatani Mohsen and Nasser Yossef MostafaInvestigating the Possibility of Utilizing Low Kaolinitic Clays in production of Geopolymer Bricks- Ceramic Silikáty (2010) 54 (2) 160-168.

[17] B. Vijaya Rangan - Fly Ash-Based Geopolymer Concrete -International Workshop on Geopolymer Cement and Concrete (2010) pp 68-106.

[18] IS: 1077-1992 "Indian Standard Code of Practice for Masonry Structure".

[19] ASTM C 67-94 "Standard Test methods for sampling and Testing. 